\title{
Irregular Migration and Its Impact on Refugee Rights
}

\author{
Neamat Mohammed Salih Mohammed \\ Faculty of Arts, Soran University, Soran, Kurdistan Region, Iraq
}

\begin{abstract}
Migration is linked to its general concept and is closely related to the right of the person to freedom of movement and choice of residence inside the borders of each state and the right to leave any country and return to it, including the state. Human migratory movements have become more complex and have taken various forms and means.

At the same time, successive waves of refugee movements and their attempts to reach a safe haven away from the dangers that forced them to leave their countries and seek asylum. For this reason, international attention has been growing by international organizations and countries in following up the problems of irregular migration and confronting the negative consequences of it. The literature of the United Nations, in particular, organizations working in this regard and countries have adopted the term irregular migration because of its characters.

Addressing the problem of irregular migration with specific rules and clear international mechanisms contributes significantly to the protection of refugees and the promotion of their rights in transit countries or in the countries of destination in which they will settle, and to clarify it's essential and important role in this regard with the provisions of the international conventions and declarations guaranteeing human rights and protecting them in such cases. In order to clarify such issues, we have chosen to explore the subject in three sections:

The first deals with the legal concept of immigration, the legal basis for its treatment and the rights enjoyed by the irregular migrant; The second section deals with the definition of asylum and its legal basis and the rights enjoyed by refugees in order to reach the most important aspects of discrimination between them; In the third section to prevent confusion between the status of migrants and refugee status, the effects of irregular migration on the asylum and refugee system and the international treatment of irregular migration and its impact on refugee rights.
\end{abstract}

Keywords: Migration, Irregular Migration, Asylum, Human Rights, Immigrants, Refugees.

\section{Introduction}

The issue of immigration is of great importance at various levels, whether at the level of enjoyment of the rights of people to move in order to settle or work or access to a safe place, or at the level of legal organization of migratory movements across international borders and to confirm their role in achieving sustainable development, As opposed to the spread and expansion of illegal immigration movements that have taken a wide range of international attention to reduce them and their negative effects on various political, security, economic, social and cultural aspects, which are increasing the concerns of States, which leads them to confront and control them?

The other level is reflected in the existence of mixed migration, which led to the overlap between the situation of migrants and refugees, although they are two different categories in several respects that need to be separated when analyzing the data of human transmission and conditions of transmission and the dangers they face and their legal status if the person is a migrant or a refugee. It led us to choose the research in these two categories and the effect of describing the irregular migrant on the description of the refugee in general. 
The Importance of the Study: The issue of refugees has also been of great importance in human and legal studies due to the increasing conditions and factors that lead to resorting to resorting to armed conflicts and the spread of terrorism and insecurity in the regions in which it is taking place. We have taken into account these studies and their importance, And its impact on the human right to asylum, using international conventions, UN resolutions and various international efforts to address the issue, in particular the efforts of the "United Nations" and the "International Organization for Migration (IOM)" and related bodies in this regard.

\subsection{The Problem of the Study}

The increase in the number of irregular migrants produced negative results, especially affecting the refugees and their right to asylum. Safety was the result of taking counter positions to accept foreign persons, of irregular migration to the human right to asylum. This has been a concern for the United Nations in its monitoring of irregular migrants, while asylum situations have increased as a result of armed conflict, persecution and insecurity in many societies. A number of questions that we will answer through the research are:

- What are the international definition of irregular migration and the status of asylum and what are the rights enjoyed by both irregular migrants and refugees?

- What are the risks posed by irregular immigration to refugee rights?

- How can the migrant be protected from the risks he or she faces before and during migration in a way that does not affect refugees?

- Are international efforts to protect migrants and refugees sufficient to protect and limit such mixing and how was its approach to action?

\subsection{The Aim of the Study}

the aim of the study is to seek to distinguish between irregular migration and the status of migrants and between refugee status and refugee status and to prevent confusion between them by examining the international efforts to determine the legal status of migrants and refugees and to ensure their protection in order to separate the cases in light of clear and clear criteria and foundations Have been established in the existing conventions, protocols and declarations in this field or are still being worked out through new declarations and ongoing international conferences calling for consideration of the problem of irregular migration and its negative repercussions on the lives of And the role played by international organizations, especially the international community, especially the important role played by the United Nations and its High Commission for the Protection of Refugees and the "International Organization for Migration (IOM)" in cooperation with States.

\subsection{The Scope of the Study}

Many studies and researches dealt with the issue of migration and illegal migration in various social, economic, security, legal, cultural and psychological aspects, indicating the vitality, importance and continuity of this subject in view of the complex problems raised by or related issues such as organized crime and trafficking of human beings, And issues of integration into the communities in which they are moving.

\subsection{The Methodology of the Study}

In order to clarify our approach in the subject, we divided the research into three topics dealing with the first definition of irregular migration and the legal basis in dealing with the clarification of the legal status of irregular migrants The second topic addresses the concept of asylum and legal basis in the treatment and rights enjoyed by the refugee to get to The distinction 
between them in the third topic, while explaining the impact of irregular migration on the asylum system because of confusion between them and international efforts to address irregular migration and the regulation of refugee situations to prevent confusion between them.

\section{Section One: Definition of Irregular Migration}

The increase in international migration and emigration reflects the growing international interest in their numbers and the attempts to find uniform global legal systems that control international migration and ensure their protection from the dangers they encounter during their flights.

In (2017) the number of international migrants, the total number of people residing in a country other than a country their birth rate was (258) million compared with (173) million in (2000) and (102) million in (1980), however, the proportion of international migrant migrants from the world population is slightly higher than the number recorded over the past decades, equal to $(3.4 \%)$ in (2017) compared to $(2.8 \%)$ in $(2000)$ and (2.3\%) in (1980).(Global Migration Indicators, 2018, p18, pp.20-21)

The total number of permanent entry in the countries of “Organization for Economic Co-operation and Development (OECD)" was just over (5) million, an increase of nearly (25\%) from (4) million in (2011) and flows in (2017) by (5\%) over (2016), the first decline since (2011), when the numbers of humanitarian migration began to increase. (Global Migration Indicators, 2018, p18, pp.20-21)

However, the downward trend in (2017) is due mainly to the decline in the number of recognized refugees, particularly in Germany and there are (80) million of them settled in Asia, (78) million international migrants in Europe, (58) million international migrants in North America, (25) million migrants in Africa and (8) million in Oceania on the Australian continent and (10) million migrants in Latin America until (2017). (Global Migration Indicators, 2018, p18, p.21)

Researchers worldwide estimate that (3540) million people migrate every (5) years, while the number of undocumented migrants was estimated (50) million irregular migrants in (2009), compared to the overall increase in international migration since then, with the potential to increase to (58) million in (2017), while the number of refugees registered with the "Office of the United Nations High Commissioner for Refugees (UNHCR)" was estimated at (25.4) million registered refugees $(102,800)$ refugees have been accepted for resettlement around the world.(Global Migration Indicators, 2018, p18, pp.22-23)

The definition of international migration and the related correlations such as irregular migration is one of the main points in the efforts to control the international migration movement in general and directing it to a beneficial destination in the direction of development and address unemployment and the eradication of poverty and hunger in the world instead of being a threat to the economies and security the lives of sending and receiving States and the difference between them and the international refugee movement their protection system.

\subsection{The Concept of Irregular Migration}

There is no unified concept agreed between countries on the term irregular migration because of the different vision and policy of each country in organizing the issue of migration and the control and management of its borders, and there was no global agreement provides for a specific definition of it, but international texts were guided by images of irregular migration Through the paths taken by irregular migrants to reach their goals, which is a reminder in the statement of meaning of irregular migration, which is decided during the discussions, resolutions, international reports and at the 
global level.

In general, migration is a migratory phenomenon, a social phenomenon known to man and animal since the creation, meaning the Turk and transition, and the term migration is used to express the departure of the original home to other citizens. The emigration is the departure of the person in the territory of his country or the state in which he resides in the territory of another country with the intention of staying in this last state permanently. Migration is a manifestation of man's struggle for survival.(Hassan Hassan Imam Sayed Al-Ahl, 2014, p.25)

According to the definition of the "International Organization for Migration (IOM)" for Migration, it means the movement of a person or group of persons, either across international borders, or within the state, which includes any type of movement, whatever its scope, composition and causes, including the migration of refugees, displaced persons, economic migrants and persons moving for other purposes, including family reunification.

Therefore, it takes several forms: circular migration means the rapid movement of peoples between countries, including temporary or long-term movement, which can be beneficial to all parties involved if they occur voluntarily and are linked to the labor needs of countries of origin and destination.(Dr. Wanisa AlHamrouni Al-Urfili, 2016, p.67)

The migration of minds is the migration of trained and talented individuals from one country of origin to another, leading to the depletion of skills resources in the State of origin and offset by the gain of minds any migration of trained individuals and talented to the country of destination they also called "Reverse Brain Drain”.(Dr. Wanisa Al-Hamrouni Al-Urfili, 2016, p.67)

Labor migration is the movement of persons from one country to another, or within their own country of residence, for the purpose of employment. Labor migration is handled by most countries in their immigration laws. In addition, some countries play an active role in organizing The migration of labor abroad and the search for opportunities for its citizens abroad, and also referred to another image, facilitating migration, which is to promote or encourage regular migration by making travel easier and more convenient, which takes the form of the process of applying for visa in a simplified manner, in any case immigration should be under the law in the sense of organization jar is the transfer of a person from the place of habitual residence to the place of new residence, in line with the laws and regulations governing the exit from the country of origin, travel and transport and enter the destination or the host country.(https://www.iom.int/key-migrationterms)

This is something that must be done with the international migrant, which was defined by the "United Nations Department of Economic and Social Affairs" in (1998) as "anyone other than the country of habitual residence" and its emigration, either short-term meaning" the person has moved to a country other than his usual residence for at least three months But not more than a year, or that his migration is long-term, i.e.," the person has moved to a country other than the country of his habitual residence for a period not less than one year.(IOM Report, 2018, p.15)

And migration in this sense either to be in accordance with the legal regulations set by each country of origin and immigration to or in violation of the laws and regulations on immigration to these countries, migration is irregular and meant movement that occurs outside the regulations of sending countries and transit and future. There is no clear or universally accepted definition of irregular migration. However, the "World Migration Report (2018)" refers to an indicative definition of it, 
indicating that irregular migration is a movement occurring outside the regulations of sending, transit and receiving countries. From the point of view of countries of destination irregular migration means entry, residence or employment without the necessary authorization or documents required under immigration laws. From the point of view of the sending State, the violation of regulations means that the management requirements are not met to leave or leave the country without a valid passport or valid travel document.(IOM Report, 2018, p312)

Migration is irregular in nature for several reasons, such as irregular entry into countries, informal residence or informal employment.(wWw.migrationdataportal.org, p.31)

In (1975), the United Nations and its specialized agencies were referred to the use of the term irregular migration. After several studies carried out by the relevant international committees associated with the United Nations, which considered labor cases, it was decided that the use of the term "irregular" migration should be a substitute for "Legal" or "Illegal", since the term "irregular" or "undocumented" is the appropriate term when referring to their status. The use of the term "Illegal" to describe migrant workers in an illegal situation is inappropriate and should be avoided because it tends to stigmatize them by associating them with the crime. The term illegal immigrants cannot be accepted because they have a normative connotation and convey the idea of criminality the term irregular migration is adopted as being more neutral.(The Economic, 2014, p.5)

The irregular migration has many images, including the entry into the country surreptitiously through the infiltration across the land border away from the eyes of the state authorities and official organs and is located within the state illegally, including illegal looting across the sea border by boarding stealthily merchant ships, which are destined to and there is also infiltration across the maritime border through illegal vessels that are equipped for this purpose. In these cases, the number of migrants is larger and in groups. These ships are often not navigable; endangering the lives of the migrants, the illegal immigration also takes the form of the manufacture of forged passports, including forged visas. These cases are frequent at land ports and air ports and are run by criminal organizations specializing in counterfeiting passports visas and other photographs. The entry of a migrant to the State shall be lawful, with a valid passport and a visa to enter the country. However, upon expiry of the period of residence granted by his passport, his presence in the country shall be illegal.

A person shall also be taken into custody by a group of persons under a contract to perform certain fixed-term work with a certain company. Upon the expiry of the contract, some of these persons may survive beyond their residence or falsify their extension documents.( Hassan Hassan Imam Sayed Al-Ahl, 2014, p.25)

Thus, a person who has taken one of the previous ways to enter the country is an irregular migrant who exposes himself to the legal countermeasures taken by each state towards this category of migrants: expulsion from the country and deportation. The EU region, for example, has seen a major trend of irregular migration by sea. Unregistered migrants have taken several dangerous sea routes to reach the EU, but the most routes since (2013) have been the center of the Mediterranean. The dramatic increase in the path of this road has tragically resulted in the death of a large number of people.(François Crepo, 2015, pp.19-20)

According to "Office of the United Nations High Commissioner for Refugees (UNHCR)"estimates, $(3,000)$ people died or lost at sea in (2014) events recorded in the 
first four months of (2015) indicate the continued alarming pace of this route and the consequent deaths among migrants, as they began to take the Aegean Sea route to reach the Greek Islands and a large number of migrants who used these channels during the period from July to September of that year.(François Crepo, 2015, pp.19-20)

In $(2017),(6,163)$ people died during migration to international destinations, the fourth consecutive year in which more than $(5,000)$ deaths and loss were recorded and at least $(2,125)$ people lost their lives during their migration to an international destination in the six months in the first half of (2018), almost half of these deaths were recorded $(1,074)$ in the middle of the Mediterranean Sea. The percentage of deaths among migrants in the Mediterranean Sea was the largest proportion of missing migrants, with $(1,339)$ deaths and disappearances, more than (90\%) of them occurred in the middle of the Mediterranean Sea.(Global Migration Indicators, 2018, p.32)

\subsection{The Legal Basis For Addressing Irregular Migration}

The regulation of migration falls within the scope of both domestic law and international law. It is subject to domestic law. Every state has the right to regulate migrants from its territory according to its interests. International law is concerned with the regulation of migration for related legal and international issues, the right, scope and legal status of the individual and his relationship with both the migrant and the migrant States. (Hassan Hassan Imam Sayed Al-Ahl, 2014, p.25)

For their part, and on the basis of their national sovereignty, States determine their national policy on migration and their right to manage migration within their jurisdiction, in conformity with international law. Within their sovereign borders, States have distinguished between the status of irregular and irregular migration, including their right to determine their legislative and policy measures, taking into account various national realities, policies, priorities and requirements regarding entry, residence and employment in accordance with international law.(The Global Agreement on Secure, orderly and orderly migration of 2018, Paragraph 15-C)

In addition to the legal regulation of irregular international migration, efforts at the global and comprehensive international level have been addressed in some international conventions, including those related to labor migration, such as those provided for in the "Protocol to the Convention against Transnational Organized Crime" to combat this type of criminal activity related to the smuggling of human beings across national borders for the year (2000), in addition to the development of new instruments that deal with migration issues and their risks, such as the "New York Declaration (2016)" and the "Global Compact For Safe, Orderly And Regular Migration (2018)".

\subsection{Basic Rights of Irregular Migrants}

Unregulated migrants across the world face many violations of their fundamental human rights. They are often subjected to arbitrary and prolonged detention because of restrictive immigration policies and may be subject to inadequate detention conditions. By law or administrative regulations, many people are denied access to public health care, adequate housing, accommodation, education and basic social security. Illegal migrant children may be unable in law or practice to go to school.

Informal migrants are often not eligible for adequate health care or decent housing, and may not be allowed to exercise their right to freedom of association. Many feel they can not inform the police when they are victims of a crime or do not send their children to school because they are afraid of being deported.(Dr. Wanisa Al- 
Hamrouni Al-Urfili, 2016, p.26)

Moreover, most irregular migrants who are forced to remain on the margins of society and are often excluded from the formal economy are forced to work in low and unorganized labor market sectors in jobs that are often dirty, dangerous and difficult may join other family members already working in these sectors. Their working conditions are often hazardous and have little or no protection to protect their labor rights. They are often subjected to exploitative conditions, including violence, torture and forced labor, with no recourse to remedies for their illegal status. (The Economic, p.12)

Despite their irregular status, this does not mean that they are deprived of their basic rights. International conventions and declarations on irregular migrants emphasize the enjoyment of basic rights that cannot be denied. The 2000 Trafficking in Persons Protocol stipulates that migrants may not be criminalized or who are irregular residents or criminalize the conduct of such persons?, while at the same time stressing the sovereign right of States to take necessary measures to counter such entry or irregular residence in their territories.(UNOV, 2014, p.47)

They also benefit from all the rights guaranteed by international human rights law in general and are guaranteed to all migrants. Everyone has the right to the enjoyment of all basic human rights and freedoms without distinction of any kind and wherever the person is, apart from being an immigrant, from the protection of all persons on its territory and subject to its jurisdiction, including irregular migrants.(HRC/29/L.3.2015)

They are emphasized in "Global Compact For Safe, Orderly And Regular Migration (2018)" which states in its fourth paragraph the right of all migrants to the enjoyment of universal human rights and fundamental freedoms, which must be respected, protected and realized to include migration in all its dimensions.
Including international declarations and charters and the rights set out in the "Protocol against the Smuggling of Migrants by Land, Sea and Air (2000)":

\subsubsection{Global Human Rights in The Global Charters}

The right to equality and non-discrimination is the cornerstone for the enjoyment of all the civil, economic and social rights of every human being. The principles of equality and non-discrimination are at the heart of international human rights law and are directly linked to the principle of universality, which affirms that everyone has fundamental rights. According to [Article (1)] of "Universal Declaration of Human Rights (1948)": "all human beings are born free and equal in dignity and rights", and according to [Article (2)]: "Everyone has the right to the enjoyment of the rights and freedoms set forth in this Declaration, without distinction of any kind".(Universal Declaration of Human Rights, 1948, Articles 1 \& 2)

“The International Covenant On Economic, Social And Cultural Rights (1966)" guarantees everyone the rights it contains, including the right to work, fair and favorable conditions of work, trade union freedoms, social security, an adequate standard of living, the right to health and education, "International Covenant on Economic, Social and Cultural Rights" in all circumstances. (The International Covenant On Economic, Social And Cultural Rights, 1966)

Under the Covenant, States have an immediate and absolute obligation in this matter. However, although this principle is firmly established in international human rights law, misconceptions about its application to non-citizens impede the full implementation of economic, social and cultural rights. In particular, irregular migrants are often discriminated against, even when this is specifically prohibited under the relevant legislation or regulations.(The Economic, p.23)

In order to protect migrants from arbitrary measures 
against them, although in an irregular situation, states must comply with their obligations under international human rights law in the management of their borders in accordance with international human rights law and other relevant standards. Including the duty to respect, protect and fulfill human rights where there is effective jurisdiction or control, including extraterritoriality, the right to due process of law, the principle of the best interests of the child and also that border management procedures should distance themselves from discrimination and the obligation to provide And the right to access to justice and redress when violations or abuses affecting human rights occur.(A/69/277)

\subsubsection{Rights of Irregular Migrants in International}

\section{Conventions on International Migration}

Under the "Protocol against the Smuggling of Migrants by Land, Sea and Air (2000)" the irregular migrant may not be considered a criminal and is covered by [Article (5)] of the "Protocol against the Smuggling of Offenders". "Migrants shall not become subject to criminal prosecution under this Protocol as they are the object of conduct set forth in [Article (6)] of this Protocol".(Protocol against the Smuggling of Migrants by Land, Sea and Air. 2000, Article 6)

Under article (16), the irregular migrant shall take measures of protection and assistance consistent with its obligations under international law, including enactment of legislation where necessary, to safeguard and protect the rights of persons who are the object of smuggling-related conduct, as accorded by international law in particular the right to of the right to life and the right not to be subjected to torture or other cruel, inhuman or degrading treatment or punishment, and to take appropriate measures to provide migrants with adequate protection from violence that may be inflicted upon them by individuals or as a target of conduct set out in [Article (6)] of the Protocol and that each State party shall provide appropriate assistance to migrants whose lives or safety are endangered and that States Parties shall take into account the special needs of women and children in the event of the detention of a person who has been the object of conduct in [Article (6)] of this Protocol, each State party under its obligations under the Vienna Convention on consular relations, where applicable, including that of informing the person concerned without delay, the provisions concerning notification and communication with consular staff. (Protocol against the Smuggling of Migrants by Land, Sea and Air. 2000, Article 16)

The other important international instrument is "International Convention on the Protection of the Rights of All Migrant Workers and Members of Their Families (1990)", which guarantees their right to equality and non-discrimination, their right to life and physical integrity, and to prevent torture, cruel treatment, the prohibition of enslavement, enslavement, forced labor and cruelty. Dangerous and dirty work, their right to personal safety, freedom of worship, access to consular or diplomatic assistance, access to legal aid, etc.(International Convention on the Protection of the Rights of All Migrant Workers and Members of Their Families, 1990)

\section{Section Two: The Definition of Asylum and the Legal Basis in its Organization}

The definition of the concept of asylum and the legal system on which it is based helps us to determine the rights enjoyed by the refugee, which are characterized in part by the rights of irregular migrants, which constitute a major chapter on which to deal with refugees from international migrants.

\subsection{The Concept of Asylum and Refugee}

Recourse to the fundamental right provided for in the “Universal Declaration of Human Rights (1948)" that everyone has the right to seek and enjoy in other 
countries asylum from persecution.(Universal

Declaration of Human Rights, 1948, Article 14-1)

International law specifically identifies and protects refugees "Refugees" are people who live outside their country of origin because of fear of persecution, conflict, violence or other conditions that are dangerous to international protection and require serious consequences for international protection.

(https://www.unhcr.org/ar/news/latest/2016/3/56e

e7ddb6)

An asylum seeker is a person who seeks safety from persecution or serious harm in a country other than his or her country and awaits a decision on the application for refugee status under relevant international and national instruments. In the case of a negative decision, the person must leave the country and may be expelled, like any non-citizen in an illegal situation, to leave or expel the country unless a permit is obtained for humanitarian or other related reason. (https://www.iom.int/key-migration-terms)

The "Refugee" status under [Article (1), Paragraph (1-a)], of the "Refugee Convention (1951)" applies to any person who has already been considered a refugee under previous international arrangements and [Article (1), Paragraph (2)] of the "Refugee Protection Protocol (1967)" provides in the context, without the time limit, a general definition of a refugee to include any person who is outside his country of origin and has no capacity or desire to return to or enjoy protection of that country because of a justified fear of persecution against Nationality or belonging to a particular group or political opinion. Stateless persons may also be refugees in this sense. At that point, the concept of a country of "Nationality" is a country of "Habitual Residence" and is not considered as a refugee within the framework of the Convention and the Protocol thereto he was a mover Nationality only if the nationality or other nationalities are not effective in the sense to extend him adequate protection. (Refugee Convention, 1951, Articles 1 \& 2) The geographical and temporal limits stipulated in the "Refugee Convention (1951)" for the Protection of Refugees have been abolished in practice as a result of developments in the international community which have led to the expansion of the definition of refugee to serve the objectives of the "Office of the United Nations High Commissioner for Refugees (UNHCR)" mandate to provide international protection to two categories of persons:

- Refugees who meet the requirements of the "Office of the United Nations High Commissioner for Refugees (UNHCR)" Rules of Procedure and [Article (1)] of the "Refugee Convention (1951)" and the "Refugee Protection Protocol (1967)".

- Who are within the scope of the extended definition of refugee within the mandate of the "Office of the United Nations High Commissioner for Refugees (UNHCR)", because they are outside their country of origin or country of habitual residence and are unable or unwilling to return there because of serious and indiscriminate threats to their lives, physical integrity or personal liberty as a result of widespread violence or seriously disrupt public order.(UNHCR Program on Self-Education, 2005, pp.8-9)

\subsection{The Legal Basis for Determining Refugee Status}

The determination of a person's status as a refugee is based on the action taken by the States of asylum where he or she has primary responsibility in defining the refugee under the refugee definition to ensure the effective use of the international protection regime and the associated rights of the refugees and to regulate its domestic laws and regulations in accordance with the obligations set out in The "Refugee Convention (1951)" and the "Refugee Protection Protocol (1967)" if the State 
is a party to them.

The process of determination of refugee status is either on an individual basis. The national legislation of the State shall state the relevant institutions or authorities and the stages of the asylum process, including determination of refugee status in the form of an individual procedure after an in-depth examination of the personal circumstances of the asylum seeker.

The process of refugee determination is on a collective basis, where recognition of the status of refugees in the context of mass influx of individuals, where asylum seekers come in large numbers and rates, which makes their application to be considered individually impractical. Often, these groups are granted refugee status based on objective information on the circumstances of the country of origin in the event of an armed conflict leading to a mass exodus of refugees to neighboring countries or to other countries. (UNHCR Program on Self-Education, 2005, pp.11-12)

Here, it should be noted that the "Office of the United Nations High Commissioner for Refugees (UNHCR)", has a role in providing international protection for refugees and that the situation varies from state to state in terms of the cooperation of countries to implement the refugee law. In practice, countries used to involve "Office of the United Nations High Commissioner for Refugees (UNHCR)", in the decision-making process related to refugees, for its part, for States to interpret the provisions of refugee conventions. (legal.un.org/avl/pdf/ha/prsr/prsr_a.pdf)

The definition of "Refugee" status is based on international refugee law and as indicated by [Article (A), Paragraph (1-A)], which states that a refugee is any person who was considered a refugee under the arrangements of (12 May 1926) and (30 June 1928) or under the (28 October 1933), (10 February 1938) and the "Protocol of (14 September 1939)", or under the
"Constitution of the International Organization for Migration".

The decisions taken by the "International Organization for Migration (IOM)" during its mandate do not preclude decisions on non-eligibility for refugee status without granting such status to those who meet the requirements in [Paragraph (2)], which provides for every person found, as a result of events that took place before (1 January) due to a justified fear of being persecuted because of his race, religion, nationality, membership of a particular social group or political views outside his country of nationality, and unable or unwilling to do so, or any person who has no nationality and is outside his or her former habitual residence as a result of such events and cannot or will not, owing to such fear, return to that country.(Constitution of the International Organization for Migration, 1939, Paragraph 2)

If a person has more than one nationality, the term "country of his nationality" means both countries of his nationality. He shall not be considered to be deprived of the protection of his country of nationality if, without any reasonable reason based on justified fear, he has not sought the protection of one of the countries of his nationality.

[Paragraph (1-B)] made it clear that the words "events prior to (1 January 1951)" in [Section (1-a) of Article (1)] should be understood to mean: (a) either "events in Europe before (1 January 1951)", or (b) "Events occurring in Europe or any other prior to (1 January 1951)", and each contracting State shall declare, ratify or accede to this Convention, these two concerns shall be taken in respect of the obligations to which this Convention is attached.(Refugee Convention, 1951, Article 1-a and b)

The Convention stipulates that it has limited space and temporal asylum according to these two paragraphs, 
which necessitated the establishment of the "Refugee Protection Protocol (1967)" relating to the Status of Refugees, which abolished the temporal and geographical dimension of refugee status and international protection.

The "United Nations General Assembly" adopted the broad concept of refugee protection that is not limited to the provisions of the "Refugee Convention (1951)" as well as other important international instruments for the protection of refugees at a regional level, including the "Convention for the Protection of Refugees in Africa (1969)", the "Cartagena Declaration of Latin America (1984)" and the "Universal Declaration of Human Rights" in general, a strong legal basis for the protection and rights of refugees.(A/AC.96/830)

\subsection{Basic Rights of Refugees}

Refugees enjoy a set of basic rights set out in the international conventions on asylum and benefit from the universal human rights contained in the international and regional international instruments because they are ultimately deprived of their humanitarian status because of the situation in which they found themselves and forced them to leave and resort.

\subsubsection{The Right of Protection against Expulsion or Retaliation}

Two main articles of the "Refugee Convention (1951)" which prohibits States Parties from expelling any refugee in their territory on a regular basis have been referred to this subject only for reasons of national security or public order.

The expulsion of such a refugee shall be carried out only in pursuance of a decision taken in accordance with the procedure prescribed by law. Unless otherwise required by compelling reasons relating to national security, a refugee must be allowed to provide proof of innocence and to exercise the right of appeal and have an agent representing him for that purpose before a competent authority or before one or more persons specifically appointed by the competent authority. Such a refugee shall be granted a reasonable time by the Contracting State to seek legal acceptance in another country. The Contracting State reserves the right to apply, within such time limit, such internal measures as it deems necessary.(Refugee Convention, 1951, Article 1,2 \& 3) [Article (33)] of the "Refugee Convention (1951)" referred to the issue of expulsions and reprisals, where the prohibition was extended to reply. The state was prohibited from expelling or returning refugees in any form to the borders or territories where their life or freedom was threatened by race, religion, nationality, Its political views, which is enshrined in [Article (33)] which accepted the principle of prohibiting the expulsion of a refugee who is in the territory of the State on a regular basis only for reasons of national security or public order, which is one of the basic principles of the law of asylum which has acquired a universal character. This refugee is to adopt a hidden decision according to the legal assets allow refugees to provide proof of his innocence, and in case if the state issued its expulsion for reasons of national security or public order, for its part, it gives him a reasonable deadline for refugees seeking entry and through which legally to another country.(Abdul Hamid Al-Wali, 2007, pp. 68-69)

It is now internationally recognized that asylum seekers cannot be reinstated or expelled until their status has been determined. Compliance with this rule applies to States parties to the "Refugee Convention (1951)" and to the "Refugee Protection Protocol (1967)" and to States not party to it, as it has become a standard in customary law.(UNHCR Program on Self-Education, 2005, p.12) Protection from retaliation is therefore a fundamental pillar of international refugee and human rights law. The prohibition of retaliation also applies when a State has a 
legal or extraterritorial jurisdiction and all arrangements are made to address the situation of persons outside territorial or other borders with the principle of nonretaliation To ensure that no person is returned directly or indirectly to territories where he or she has faced persecution, the threat of real torture or arbitrary deprivation of the right to life or irreparable harm. This rule applies to persons officially recognized as refugees and to a petitioner Asylum until a final settlement of their claims.(Protection Policy Document- Maritime Conflicts and Handling of International Protection Applications: Legal Standards and Policy Considerations on Extra-territorial Remedies, UNHCR, International Protection Section, 2010, Paragraph 3)

\subsubsection{The Basic Rights of Refugees}

Refugees enjoy basic rights that combine rights in asylum law with international human rights law.

They are civil, economic and social rights, such as the right to non-discrimination, freedom of religion, personal status such as marriage, ownership of movable and immovable property, as regulated by the laws of the state of asylum, and no less than regulations governing foreigners, The right to work, free professions, the right to education, employment, social security, freedom of movement, the right to travel documents and the right to identity cards.(Refugee Convention, 1951, Paragraphs 3-5, 12-19, 22, 24, \& 26-28)

\subsubsection{Rights of Non-Regular Refugees}

[Article (31)] of the "Refugee Convention (1951)" refers to another category of refugees who are illegally present in the country of asylum it stipulated that Contracting States shall refrain from imposing penal sanctions, on account of their illegal entry or presence, of refugees who enter or reside in their territory without permission coming directly from a territory in which their life or liberty is threatened in the sense of article of the Convention, provided that they present themselves to the authorities without delay and prove the reasonableness of their reasons for entry or illegal presence.(Refugee Convention, 1951, Article 31)

States Parties shall also refrain from imposing unnecessary restrictions on the movement of such refugees, and shall apply such restrictions only until their status in the country of refuge is settled or pending acceptance in another country.

Contracting States shall grant the said refugees a reasonable period of time, as well as all necessary facilities, to obtain the admission of another country.

\section{Section Three: The Effects of Irregular Migration on the Asylum System and Ways of Confronting It Internationally}

The confusion between the situation of the migrant and the refugee is justified in the receiving countries and societies of these two distinct categories of interference related to the conditions of movement of these groups and the means they have followed to reach their destination as well as the lack of legal definition of the term migration and irregular migration, especially in the context of mixed human movements, Counter-action and non-acceptance of expatriate persons in general in exchange for the intensification of international efforts to reduce confusion in ways consistent with basic human rights and respect the status of each of them as an immigrant or refugee, and his messengers in this chapter.

\subsection{Confusion between Immigrant Status and Refugee}

\section{Status}

Although the legal framework governing the treatment of refugees is separate from that governing the treatment of migrants, both categories have recognized human rights and fundamental global freedoms.

Both face many common challenges and both have similar weaknesses, including those in the context of major displacement movements that reflect a number of 
considerations, including: the number of arrivals, the economic, social and geographic context, the capacity of the receiving State to respond, and the effects of sudden or long-term displacement.

The term, however, does not include, for example, regular flows of migrants from one country to another. Major movements of displacement may include mixed flows of persons, whether refugees or irregular migrants, who migrate for various reasons but may use similar routes.

Major displacement movements of refugees and migrants have political, economic, social, developmental, human and human rights implications that transcend geographical boundaries, global phenomena that require global policies and need global solutions.

No single State can deal with these displacement movements on its own, and these movements have an adverse effect on neighboring countries or transit countries, most of which are developing countries, which in many cases have far too much of the capacities of those countries.

On the other hand, refugees and displaced migrants in the context of large displacement movements often face scourges of hope, many of them at great risk, on risky trips, many of whom may not survive, and some find themselves forced to use the services of criminal gangs, as smugglers' gangs. Others may be prey to these gangs or victims of trafficking. Even if they get where they want, they are not sure what kind of reception they are and what they face in the future. Racist acts, and racial discrimination Xenophobia and related intolerance against migrants and refugees, and stereotypes often attached to them on grounds such as religion or belief.(New York Declaration, 2016, Article 6, 9, and 14) Regardless of the reasons that led them to emigrate or resort and the dangers they face in the case of expulsion and return to the source of danger and persecution and violence, and therefore have agreed conditions and similar means to reach the destinations of the destination, which has eliminated all the discrimination in some cases in dealing with irregular migrants who Does not apply for asylum, and the refugee, especially the illegal, who cannot return to the country of his presence from which he fled.

On the other hand, the absence of a legal definition of the universally accepted term of immigration has played a major role in confusing the two categories of migrants and refugees. Some decision-makers, international organizations and media have understood the term migrant and used it as a universal term encompassing migrants and refugees. International Statistics on International Migration A definition of international migration to include migrants, refugees and asylum seekers

These practices easily lead to confusion and carry significant risks to the lives and safety of refugees and the confusion between refugees and migrants thus diverts attention from the specific international protection that a refugee needs.

(https://www.unhcr.org/ar/news/latest/2016/3/56e e7ddb6.html)

For example, the unified term used by the "International Migration Report (2015) that was published by "Economic and Social Commission for Western Asia (ESCWA)", "Mixed Migration", which included various categories of people, including refugees, indicated that migration waves mixed in the Arab Region when people seek to escape conflict, rampant violence, persecution, disruption of public order, famine, drought, the desire to join family members abroad, escape economic hardship, and seek better livelihoods and opportunities for life abroad.(E/ESCWA/SDD/2015/1)

"Mixed Migration" refers to complex population 
movements, including waves of refugees, displaced persons, asylum seekers, workers, and others.

This migration is a pervasive global phenomenon that poses major challenges in ensuring equal protection for all migrants who may take the same means of transport but move for various reasons. (E/ESCWA/SDD/2015/1)

This group of individuals shares patterns of migration and roads and is subject to study as a single category. Mixed migratory waves include persons who do not have identification documents, who cross the border to reach the destination illegally as they take dangerous roads across the desert or the sea. They travel in unsafe vehicles and travel in extremely dangerous conditions. Migrants often rely on organized crime networks to act in secret in operations contrary to any type of system and cannot seek assistance to seek justice through the usual mechanisms. (E/ESCWA/SDD/2015/1)

It is clear that this clear confusion of the term migrant and its generalization to the refugee will reduce or even eliminate the opportunity of refugees and asylum seekers to obtain a fair protection system, especially with the emphasis placed by States in controlling their borders and dealing with irregular migration in ways different from those adopted with refugees, The most prominent of which is their status in camps waiting to be sent home without any distinction between those who are prevented by real reasons of return and those who want to improve their economic status or join their families or forced by natural conditions related to climate to migrate in this irregular way.

In other cases, the term "forced migration" is used as a general and open term that includes many types of involuntary displacement and movements across both international and intra-State borders and its use to refer to persons displaced for reasons of conflict, natural disaster, famine, This would include the reference to refugees as forced migrants, rejected by the "Office of the United Nations High Commissioner for Refugees (UNHCR)" for the existence of fundamental differences between the terms on the one hand, the "Refugee" is a legal concept defined in international conventions that establish specific legal obligations on States, while "Forced Migration" is a social term and has no universally accepted concept. A reference to a refugee in this capacity will deprive a refugee of his or her specific refugee needs, impede the implementation of universally agreed legal obligations for the protection of refugees and create confusion in the treatment of persons fleeing risk as refugees. (E/ESCWA/SDD/2015/1)

In the previous position, "Economic and Social Commission for Western Asia (ESCWA)" used this term to include refugees when it adopted the definition of "forced migration": "the movement of migration in which pressure and coercion exists, including the fear of persecution and the danger to life and livelihood, Whether by man or by nature, such as asylum, displacement due to natural disasters or internal displacement, by environmental disasters, chemical or nuclear disasters, famine or development projects. "

While at the same time recognizing the difficulty of distinguishing between different people in their circumstances, especially that the waves of mixed migration, which are forced to multiply in situations of conflict and political instability, such as in the Mediterranean, or the Gulf of Aden when small boats and Asylum seekers, and other people seeking security or economic opportunities. It was clear from here and from the diversity of countries of origin from which most of those who crossed the Mediterranean in early 2015 that it was difficult to differentiate between asylum seekers or those seeking economic opportunities. The countries of Eritrea, and countries of South Africa Syria, 
the Syrian Arab Republic, Somalia and Iraq, most of which are experiencing conflict and violence that endanger citizen and economic security. (E/ESCWA/SDD/2015/1)

Therefore we can prove that it is not appropriate to adopt these broad concepts and apply them to the refugee status defined internationally and legally.

\subsection{The Consequences of Confusing the Status of Immigrant and Refugee}

The confusion between the terms "irregular migrant" and "Refugee" distinguishes attention from the specific legal protection that refugee's need, such as protection from forced return and punishment to cross borders in search of safety without authorization. There is nothing illegal in seeking asylum- on the contrary, asylum is a human right. The confusion between the terms "Migrant" and "Refugee" may also reduce public support for refugees and the issue of asylum at a time when more refugees need this protection than ever before. (UNHCR, International Protection Section, 2010, Paragraph 3)

Which impede the application of international protection regimes for refugees and not to benefit from the provisions of [Articles (32) and (33)] of the "Refugee Convention (1951)", which we referred to in the second section, which prevented the expulsion of refugees or their return to the border or to the regions feared for their safety, customary in international refugee law and rules for the protection of human rights globally. They are dealt with in strict accordance with irregular migration and the consequent tightening of international border management procedures and detention in places where conditions for the enjoyment of basic human rights are not met. The possibility of imposing sanctions on them as a result of their treatment of irregular migrants under the domestic regulations of the countries they objected to.

\subsection{Aspects of Discrimination and International} Remedies for Irregular Migration and Refugee Status

Ensuring the prevention of human flows through irregular movements through internationally agreed procedures and cooperation between all relevant international organizations, States, civil society organizations and others is a matter of concern to the international community and resulted in the development of three important international instruments whose primary task is to distinguish between migrants and refugees, Define the basic international protection of the two categories

The distinction between irregular migration and the right to asylum is central to the work of the international bodies that are considering the protection of the rights of the two categories of people, especially the "Office of the United Nations High Commissioner for Refugees (UNHCR)", which has taken on the task of clarifying the difference between them, together with the efforts of States and the world organization.

The "United Nations" in support of the global trend to adopt two independent charter, one of which is safe migration, its mechanisms and procedures for (2018) and the other on refugees for (2018), which we will explain below, especially after the adoption of the "New York Declaration (2016)".

\subsubsection{Aspects of Discrimination}

Through the study of irregular migration and its different from the state of asylum, there are basic points that facilitate the process of discrimination. This is a reference to people who are moving in mixed movements in the name of a refugee or an immigrant, because of the different indications. Each refugee is found outside the country of origin and cannot return. For fear of being subjected to violence or persecution, the conflict or security conditions is a serious breach, unlike 
an irregular migrant whose motives may be economic migration, security or welfare, or contact with his family to other circumstances that enable him to return to his country of origin .

Therefore, there is a clear distinction between the refugee protection system and the general human rights rules and the specific obligations that are different for the refugee in detailing the migrants, as we shall explain below in the third requirement, in addition to the nature of the rights enjoyed by the refugee, or to respond to refugees who do not have the option of returning to the danger centers that threaten their existence and safety, while the irregular migrants do not enjoy such a right, but follow procedures consistent with universal human rights standards in general.

\subsubsection{International treatment methods}

There is a wide range of measures adopted to deal with the situation of migrants and refugees. Here we try to highlight the general basic rules in this subject because of the complexity and the capacity that characterizes it. It can be clarified in three basic points:

- Addressing the applications of persons seeking international protection, three methods are taken.

a. Pre-screening is a process that precedes the formal determination of refugee status. It aims at identifying and distinguishing categories of applicants, such as those seeking international protection, victims of human trafficking and irregular economic migrants. Its main components include providing information on new arrivals and collecting Information about them through informal questionnaires and interviews, the initial work of each of them and the provision of advice to them. If their status as refugees is determined or their request for temporary international protection is accepted, Decision in the "international protection system," one of the basic guarantees, is resettlement in the country which accepted them for the refugees, including accompanied by fundamental rights, and we have mentioned previously.

As for those who benefited from the temporary protection, they expect the need for protection for a short period, during which they enjoy freedom of movement and self-reliance to live with the possibility of returning them to their country of origin, and except for these cases, the people who have been detected not to need protection is the solution available to them in general is Bringing them back to their country of origin, as is the case with irregular migrants.

b. The second treatment is to determine the status of the refugee by applying for protection to a specialized and professional body and to conduct personal interviews from the first moment with a formal decision regarding the request and the possibility of objecting to the negative decision.

c. The third treatment is in the form of temporary protection, especially for persons coming in groups who are assessed initially in general and usually need short-term protection.

These three measures have been adopted in relation to persons seeking international protection, whether by the State objecting to them within their territory, as it is consistent with the responsibilities of this State towards persons under its jurisdiction or actual jurisdiction,

Or the situation of these persons may be assessed by countries outside the borders of the State of Objection as part of the burden of cooperation between States to deal with refugee situations and other mixed movements such as irregular migrants and victims of trafficking.(UNHCR, International Protection 
Section, 2010, Paragraph 4)

- International commitments on migrants, particularly under the "New York Declaration (2016) and the "World Charter for the Protection of Refugees (2018)", orderly migration to address the situation of migrants.

- International refugee status obligations based on the Refugee Protection Act, the "New York Declaration (2016) and the "World Charter for the Protection of Refugees (2018)".

\subsection{Basic Procedures for International Protection}

There is a wide range of measures adopted to deal with the situation of migrants and refugees. Here we will try to highlight the general rules of protection of migrants from refugee protection rules and the obligations of the international community on this issue. Basic, through the basic features of the protection of the two categories are:

\subsubsection{Addressing Requests of Persons Seeking International Protection}

Three methods are used. Pre-screening, a process that precedes the formal determination of refugee status, aims at identifying and distinguishing groups of applicants and those seeking international protection, trafficking victims and irregular economic migrants.

Its main components include providing information on new arrivals, collecting information about them through questionnaires and informal interviews, providing a preliminary file of each of them, providing advice to them, and if their status as refugees is determined or their request for temporary international protection is accepted, According to the decision in the "International Protection System", one of its basic guarantees is "Resettlement" in the state that it has accepted for refugees with the basic rights that we have already referred to.

Those who benefited from "temporary protection" would be expected to need protection for a short period, during which they would enjoy freedom of movement and self-reliance to live, with the possibility of returning them to their country of origin.

With the exception of these two cases, people who have been detected not to need protection, the solution available to them in general is as follows:

- They were sent back to their original country, as is the case with irregular migrants.

- The second treatment is to "Determine Refugee Status" by applying for protection to a professional and professional body, conducting personal interviews from the first moment with a formal decision on the request, and the possibility of opposing the negative decision.

- The third treatment is in the form of "Temporary Protection", especially for people coming in groups who are assessed initially in general and usually need short-term protection. (UNHCR, International Protection Section, 2010, Paragraphs 4,5 \& 6)

These three remedies have been adopted for persons seeking international protection, whether by the state they have intercepted within their territory, as it complies with the responsibilities of this state towards persons who are subject to its jurisdiction or actual jurisdiction or may be dealt with within countries outside the borders The territory of the State of Objection as part of the inter-State cooperation in burdening and dealing with refugee situations and other mixed movements such as irregular migrants and victims of human trafficking.

4.4.2 International Commitments on Migrants, Particularly under the "New York Declaration (2016) and "World Charter for the Protection of Refugees (2018)"

This is as follows: 
- To protect the safety of all migrants, to protect their dignity, human rights and fundamental freedoms, at all times, to guarantee their rights, to protect their interests and to provide them with assistance, inter alia, by providing consular protection, assistance and cooperation in accordance with International law.

- Addressing or exacerbating factors leading to or exacerbating major displacement movements, analyzing and contributing to factors contributing to the occurrence of such movements, including factors in countries of origin, and cooperating to The conditions that enable communities and individuals to live in peace and prosperity in their home countries, migration should be an unnecessary option.

- Facilitate safe, orderly and legal migration opportunities, including, where appropriate, job creation, mobility of labor at all levels of skills, circular migration, family reunification and opportunities for education.

- Encourage cooperation among countries of origin or nationality, transit countries, countries of destination and other relevant countries to ensure that migrants without a permit to reside in the country of destination can, in accordance with the international obligations of all States, To their country of origin or to the country of their nationality in a secure and orderly manner that preserves their dignity, preferably on a voluntary basis, provided that this is consistent with international human rights law, taking into account national legislation in line with international law, and taking advantage of the subject of organized international migration in safe and systematic ways in the area of sustainable development.(New York Declaration, 2016, Paragraphs 22-63)
Therefore, the main feature of reducing irregular migration was to address the situations of countries where people migrated to create conditions of stability in their countries, while encouraging safe migration, which is used in the process of human development through international corridors in a systematic manner by States in accordance with international standards in dealing with Which will guarantee their safety, rights and assistance in accordance with the norms of international human rights law.

As well as the emphasis on cooperation in facilitating the return of migrants and allowing their safe and dignified return, as well as their sustainable reintegration, by only facilitating and cooperating with safe and dignified return, ensuring due process, taking individual status and equity And the return of migrants, where there is an actual and foreseeable threat of death or subjected to torture and other cruel, inhuman or degrading treatment or other irreparable harm, Emphasizing their right to return to their homelands, but by creating favorable conditions for personal safety, economic empowerment, integration and social cohesion in communities in order to ensure the sustainable reintegration of migrants upon their return to their countries of origin.

In order to ensure the above, work on bilateral, regional and multilateral agreements allows for safe and dignified access to their countries in accordance with international human rights standards and facilitates their sustainable reintegration.(World Charter for the Protection of Refugees, 2018)

\section{Conclusions}

- International attention to the situation of migrants and refugees within the broad human movements takes an important part of the work of international organizations and their organs and States, thus protecting them on a range of international and regional international instruments, including the 
"International Protocol against the Smuggling of Migrants of (2000)", “Convention against Transnational Organized Crime (2000)".

- In terms of refugees, the "Refugee Convention (1951)" its "Refugee Protection Protocol (1967)", the "Convention for the Protection of Refugees in Africa (1969)", and the "Cartagena Declaration of Latin America (1984)" were also included.

- Emphasizing the importance of distinguishing between the range of irregularly moving people as migrants for various economic, social or security reasons, and the range of persons fleeing from death, persecution, armed conflict, insecurity and public order, such as refugees, given the danger of confusion between the two categories, deprive him of his basic rights under international law of asylum, the first of which is the right to seek asylum and "Forced Return".

- The coordination of international efforts to achieve a clear separation between the term migrant and irregular migrants and the means of dealing with them under the rules of International Law for Human Rights

- The term refugee and its consequent obligations and distinct means of protection under the international law of asylum and the rules of international human rights law in the development of the "New York Declaration (2016)" detailing the provisions of the Declaration in two international agreements, one specifically for migrants of (2018) and the other for refugees in (2018) Takeda Stressed the importance of distinguishing between migrants and refugees.

- Unregulated migration is a movement that occurs outside the regulations of the sending, transit and receiving countries. Individuals who travel outside the regulations are called "Irregular Migrants", which in any case require treatment in accordance with the basic standards of international human rights law, noting that the origin of their cases is to return home by ensuring safe means for their safety unless they are in real danger and being scrutinized by the receiving countries.

- A refugee is a person who is outside his country of origin or habitual residence and cannot or will not return because of serious and indiscriminate threats that endanger his life, physical integrity or personal liberty as a result of widespread violence or serious disturbance of public order. The prohibition of expulsion and return to the borders or territories in which he fears for his life, safety or liberty, even if he has arrived in an irregular manner, he shall benefit from this fundamental rule and an exception to which the State may take these measures against him but on conditions that ultimately guarantee his rights challenging the decision Safety and security in the event of the appeal and the response out of the state after a reasonable period of time to ensure a transition to a safe place shall be subjected to his life or physical integrity real danger.

- The intensification of international efforts, although eventually aimed at improving the protection of these two groups, especially the adoption of the “New York Declaration (2016) and the establishment of two international agreements in (2018), one for "Immigrants" and the other "Refugees", but in the end came in a non-mandatory format to guide countries in future work with migration issues international refugee status, i.e. that the entry into force of mandatory international protection would be under the binding international conventions in these two subjects.

- The obligations of States under the International Covenants on Human Rights, the "Protocol Against Illegal Immigration (2000)", the "Refugee 
Convention (1951)", the "Refugee Protection

Protocol (1967)" thereto, and the "Office of the United Nations High Commissioner for Refugees (UNHCR)" system with universal human rights norms.

\section{Recommendations}

- To issue a clear and detailed guide by the United Nations to standardize the terms of immigration, asylum and displacement in order to avoid ambiguity in this context and to serve migrants, refugees and displaced persons to facilitate the application of international conventions and national laws to that situation.

- Follow-up of cases of migration, asylum and mass exoduses, in order to enhance the state of control of States' implementation of their own State's.

- Follow up the causes of migration and mass exodus in order to identify the reasons for developing common international needs to overcome these problems.

- Disseminate public knowledge about the rights that the international community has ratified in relation to migration, asylum and displacement, particularly in communities suffering from migration and mass exoduses, to enhance their understanding of their rights.

\section{References}

1. Abdulhamid Al-Wali, 2007, The Question of International and Arab Asylum: Commentary on the United Nations Convention on Refugees, I, Besan Publishing and Distribution, Beirut, Lebanon.

2. Dr. Hassan Hassan Imam Sayed Al-Ahl, 2014, Combating Illegal Immigration in Light of International Responsibility and the Provisions of the International Law of the Sea, University Thought House, Alexandria, Egypt.

3. Dr. Al-Hamrouni Al-Urfili, 2016, Church, Illegal Immigration in Western Mediterranean Countries: Study in the Regional Association, Dar Al-Fikr Al-Arabi, Alexandria, Egypt.

4. Report of the World Organization for Migration, World Migration, 2018.
5. GLOBAL MIGRATION INDICATORS، Insights from the Global Migration Data Portal‘2018 www.migrationdataportal.org

6. Report of the Special Rapporteur on the human rights of migrants, François Cribo, A Decade of Mobility: Followup to the Regional Study on External Border Management of the European Union and its Impact on the Human Rights of Migrants, International Council on Human Rights, Promotion and protection of all economic and social rights, including the right to development, 8/5/2015

7. GLOBAL MIGRATION INDICATORS, Insights from The Global Migration Data Porta.

8. GLOBAL MIGRATION INDICATORS INSIGHTS FROM THE GLOBAL MIGRATION DATA PORTAL 2018.WWW.MIGRATIONDATAPORTAL.ORG

9. World Organization for Migration, Migration conventions https://www.iom.int/key-migration-terms

10. THE ECONOMIC، SOCIAL AND CULTURAL RIGHTS OF MIGRANTS IN AN IRREGULAR SITUATION, United Nations, Human Rights Office of the High commissioners, NewYork,2014.

11. Protocol against the Smuggling of Migrants by Land, Sea and Air, supplementing the United Nations Convention against Transnational Organized Crime, 2000.

12. Universal Declaration of Human Rights of 1948.

13. Convention relating to the Status of Refugees of 1951.

14. JS Goodwin Jill, 1951 Convention relating to the Status of Refugees and its Protocol, research published on the UN website: legal.un.org/avl/pdf/ha/prsr/prsr_a.pdf

15. The International Covenant on Economic, Social And Cultural Rights (1966).

16. Memorandum of the Executive Committee of the United Nations High Commissioner for Refugees, Note on International Protection - 1994-1995, Document No. (A/ AC.96/830).

17. Legislative Evidence for the Implementation of the United Nations Convention against Transnational Organized Crime and the Protocols thereto: Legislative Guide for the Implementation of the Protocol against the Smuggling of Migrants by Land, Sea and Air, supplementing the United Nations Convention against Transnational Organized Crime, Part III, United Nations Office on Drugs and Crime, New York 2004.

18. UNHCR Program on Self - Education, Refugee Status Determination 2005, printed with funding from the European Commission, 2005.

19. Protection Policy Document - Maritime Conflicts and Handling of International Protection Applications: Legal Standards and Policy Considerations on Extra-territorial Remedies, UNHCR, International Protection Section, Paragraph III, 2010.

20. Report of the Secretary-General of the United Nations, Promotion and protection of human rights, including 
ways and means of promoting the human rights of migrants, transmitted to the General Assembly, Sixtyninth Session, 2014, Document No. 277/69.

21. International Migration Report: Migration, Displacement and Development in a Changing Arab Region, prepared by the ESCOL Program for Countries and the International Organization for Migration, 2015, E/ESCWA/SDD/2015/1.

22. The New York Declaration on Refugees and Migrants adopted by the General Assembly at its 71st Session, item 13 and 14 of 19 September 2016, A/71/L.1.

23. United Nations High Commissioner for Refugees, Refugees and Migrants, Common Questions, March 2016. https://www.unhcr.org/ar/news/latest/2016/3/56ee7 ddb6.html.

24. UNHCR on these risks in the confusion of irregular migrants and refugees, in its publication Refugees and Migrants Common Questions, 2016, published on the websit https://www.unhcr.org/ar/news/latest/2016/3/56ee7 ddb6.html

25. Global Agreement for Secure, Organized and Regulatory Migration of 2018.

26. Global Agreement on Secure, Organized and Statutory Migration for 2018.

27. United Nations، Treaty Series، vol. 189، No. 2545.

28. Report of the High Commissioner for Refugees, Part II, Global Agreement on Refugees, 2018 Document No. A/73/12 (Part II), published on the website https://www.unodc.org/pdf/crime/legislative_guides/ 04\%20Arabic\%20Legislative\%20guide_Smuggling\%20of \%20Migrants \%20Protocol.pdf.

29. Human Rights Council resolution: Promotion and protection of civil, political, economic, social and cultural rights, including the right to development - Protection of the human rights of migrants: transit migrants - 29 th Session, /29/L.3.

30. World Organization for Migration, published on the website: https://www.iom.int/key-migration-terms

31. UNHCR: Self-Education Program, Refugee Determination. 